\title{
Correlation and path coefficient analysis between yield and yield components in potato (Solanum tuberosum L.)
}

\author{
Abraham Lamboro, Yohannes Petros and Mebeaselassie Andargie ${ }^{\otimes}$
}

\begin{abstract}
The associations of yield and its components offer important information in breeding plants. A study was conducted at the Araka Agricultural Research Center, Hossana, Ethiopia during 2012 growing season under rain fed condition on 18 potato genotypes/varieties to determine the association of yield and its components. The association was analyzed by correlation coefficient, and further subjected by path coefficient analysis to estimate direct and indirect effects of each character on tuber yield. Positive and significant correlation were found between tuber yield and biological yield, plant height and tuber yield, stems per plant and tuber per plant. The genotypic correlation coefficients were higher than the corresponding phenotypic correlation coefficients for most of the characters indicating the inherent association among the characters. Path analysis of tuber yield and its components shows that stems per plant, biological yield and harvest index exerted positive highest direct influence on tuber yield indicating their importance as selection index for yield improvement.
\end{abstract}

Keywords: correlation coefficient; path analysis; potato; Solanum tuberosum; yield component

\section{Introduction}

Potato (Solanum tuberosum L.) is one of the most important horticultural and economical food crops in Ethiopia as well as many countries of the world. Potato,

Received: 04 August 2014 / Accepted revised version: 17 September 2014 / Published online: 03 October 2014

(C) Horizon e-Publishing Group

CITATION

Abraham, L., Yohannes, P., \& Mebeaselassie, A. (2014). Correlation and path coefficient analysis between yield and yield components in potato (Solanum tuberosum L.). Plant Science Today, 1(4), 196-200. http://dx.doi.org/10.14719/pst.2014.1.4.79

AUTHOR'S AFFILIATION

Biology Department, College of Natural and Computational Sciences (CNCS), Haramaya University, P.O. Box: 138, Dire Dawa, Ethiopia

CORRESPONDENCE

凶Dr. Mebeaselassie Andargie, e-mail: mebhel@yahoo.com due to having high nutritional value, is considered as a very important crop in feeding the developing countries of the world. It is also a world leading vegetable crop that furnishes appreciable amount of vitamin B and vitamin C as well as some minerals (Thompson \& Kelly, 1957). Generally, potato produces more calories and protein per unit land area with minimum time and water than most of the major food crops (Upadhya, 1995). Potato production in Ethiopia covers an area of about 1600, 000 ha. The average yield of potato in Ethiopia is 9 tones/ha which is much lower than the world average yield 15 tones/ha (Ferdu et al., 2009).

As yield together with good quality is the main object of a breeder, so it is important to know the relationship between various characters that have direct and indirect effect on yield. Yield is a complex character associated with many interrelated components (Murat \& Vahdettin, 2004). Previous reports by Birhman \& Kang (1993); Amadi (2005) and Amadi \& Ene-Obong (2007) showed that simple correlation coefficients were useful to study the interrelationships between tuber yield and other characters. However, information about the correlation of agronomic and morphological characters with yields is helpful in the identification of the components of this complex character, yet these do not provide precise information on the relative importance of direct and indirect influences of each of the component characters. The knowledge of association of quantitative characters, especially the yield and its attributes provide an idea of association that could be effectively utilized in selecting the desired characters in a segregating population. With increasing number of variables it becomes necessary to measure the contribution of these variables to the observed correlation and hence partition the correlation coefficient into components of direct and indirect influence (Guler, Adak, \& Ulukan et al., 2001, Onder \& Babaoglu, 2001). This in turn allows separation of the direct effects of one variable from indirect effects of other variables by keeping other variables constant in order to give a clearer picture of the individual contributions of each variable to yield (Radovan, 1992). Since path analysis permits a 
critical examination of the specific factor that produces a given correlation, it could be successfully employed in formulating an effective selection strategy (Kumbhar, Larik, \& Hafiz, 1980). Generally, a path coefficient analysis is needed to clarify relationship that exists between characteristics, because correlation coefficients describe relationships in a simple manner. In most studies involving path analysis, researchers considered the predictor character as first-order variables to analyze their effects over dependent or response variable such as yield (Tuncturk \& Ciftci, 2005). The objective of the present study was to evaluate tuber yield components and their interrelationship by path analysis.

Table 1. Potato genotypes/varieties used in the study and their sources

\begin{tabular}{cll}
\hline S.No & Variety & Source \\
\hline 1 & Bolbo & Local \\
2 & Bubu & Haramaya \\
3 & Gera & Holeta \\
4 & Bule & Holeta \\
5 & Belete & Holeta \\
6 & Gudanie & Holeta \\
7 & Menegesha & Holeta \\
8 & Wochecha & Holeta \\
9 & Awash & Holeta \\
10 & Chiro & Haramaya \\
11 & Marachera & Holeta \\
12 & Guassa & Holeta \\
13 & Gorobella & Holeta \\
14 & Bedassa & Haramaya \\
15 & Jalanie & Holeta \\
16 & Sako & Local \\
17 & Challa & Holeta \\
18 & Zengena & Holeta \\
\hline
\end{tabular}

\section{Materials and Methods}

The study was carried out at Araka Agricultural Research Center, Hossana, Ethiopia during 2012 growing season under rain fed condition. It has an average annual rain fall of about $671 \mathrm{~mm}$ and annual mean temperature of $18^{\circ} \mathrm{C}$ and has loam soil type (SNNPRFEDB, 2010). The altitude is $2200 \mathrm{~m}$ from sea-level. Sixteen potato varieties, which were released by the regional and national research institutions at different times and two locally available potato genotypes were used for this study (Table 1). The experiment was laid in a randomized complete block design with three replications. Each variety/genotype was planted in $3 \mathrm{~m} \times 3 \mathrm{~m}$ plots maintaining row to row spacing of $75 \mathrm{~cm}$ and plant to plant in a row spacing of $30 \mathrm{~cm}$. Each plot consisted of four rows which accommodated ten plants per row and thus forty plants per plot. A distance of $1 \mathrm{~m}$ was maintained between the plots. All recommended agronomic practices were followed including application of fertilizers when it is required. Agronomic characters were determined on the means of five randomly selected plants in the middle rows of each plot.

Days to emergence (number of days from planting to the emergence of $50 \%$ of plants), days to flowering (number of days from planting to when $50 \%$ of the plants in a plot produced flowers on $50 \%$ of their buds), days to maturity (number of days from planting to when $90 \%$ of the plants in a plot reached physiological maturity), plant height (cm), main stems/plant (i.e. those originating from the mother tubers were counted), tuber yield $(\mathrm{kg} / \mathrm{ha})$, tuber/plant, biological yield (kg), harvest index (average tuber yield divided by the average biological yield), small tuber $(20-35 \mathrm{~mm})$ percentage $(\%)$, medium tuber $(30-$ $55 \mathrm{~mm})$ percentage $(\%)$, big tuber $(>55 \mathrm{~mm})$ percentage (\%) were determined. Genotypic ( $\mathrm{rg}$ ) and phenotypic (rp) correlation coefficients were determined as described by Kwon and Torrie (1964). Path coefficient analysis was carried out using the phenotypic correlation coefficients as well as genotypic correlation coefficients to determine the direct and indirect effects of the yield components and other morphological characters on seed yield. Path coefficient analysis was also conducted to determine the direct and indirect effect of various traits on seed yield using the general formula of Dewey and Lu (1959).

\section{Results and Discussion \\ Correlation Coefficients}

The results of the correlation coefficients (Table 2) revealed phenotypic and genotypic correlation coefficients between yield and its contributing characters in potato. In majority of the cases, the genotypic correlation coefficients were higher than the corresponding phenotypic correlation coefficients. Modifying or masking effect of environment in the expression of these characters under study is one possible reason for the presence of a higher genotypic correlation than phenotypic ones (Nandipuri, Singh, \& Lal, 1973). Johnson, Robinson, \& Comstock, (1955) also reported that higher genotypic correlation than phenotypic correlation indicated an inherent association among the various characters. In this study high positive significant correlation was found between tuber yield and biological yield, plant height and tuber yield, tuber per plant and small tuber percentage, stems per plant and tuber per plant. There were significant correlations among the yield contributing characters also. Days to maturity had high significant positive correlation with biological yield. Plant height and biological yield, tuber yield and plant height had high significant positive associations. This indicates that increase in positively associated characters contributes in order to increase yield per plant. Yildirim, Çalikan, Çaylak, \& Budak, (1997); Galarreta, Ezpelata, Pascualena, \& Ritter, (2006) and 
Table 2. Phenotypic (above diagonal) and genotypic (below diagonal) correlation coefficient among potato traits.

\begin{tabular}{|c|c|c|c|c|c|c|c|c|c|c|c|c|}
\hline Trait & DE & DF & DM & PH & SP & TY & TP & BY & HI & STP & MTP & BTP \\
\hline DE & 1 & $0.442^{* *}$ & $0.364^{* *}$ & -0.011 & $-0.361^{* *}$ & 0.156 & $-0.337^{*}$ & 0.262 & -0.237 & -0.131 & -0.118 & -0.010 \\
\hline DF & $0.513^{* *}$ & 1 & -0.082 & -0.263 & 0.152 & -0.006 & 0.169 & 0.163 & -0.094 & 0.056 & -0.202 & 0.145 \\
\hline DM & $0.410^{* *}$ & -0.084 & 1 & $0.313^{*}$ & -0.202 & 0.100 & $-0.469^{* *}$ & $0.362^{* *}$ & -0.138 & -0.101 & -0.082 & 0.179 \\
\hline SP & $-0.406^{* *}$ & 0.163 & -0.214 & 0.100 & 1 & $0.289 *$ & $0.449 * *$ & 0.246 & -0.028 & 0.135 & 0.073 & 0.094 \\
\hline TY & 0.186 & -0.007 & 0.110 & $0.615^{* *}$ & $0.318^{*}$ & 1 & -0.008 & $0.653^{* *}$ & 0.001 & $-0.423^{* *}$ & $0.314^{*}$ & 0.015 \\
\hline TP & $-0.400^{* *}$ & 0.191 & $-0.512^{* *}$ & 0.145 & $0.491^{* *}$ & -0.015 & 1 & -0.051 & 0.193 & $0.601^{* *}$ & $-0.337^{*}$ & 0.148 \\
\hline BY & $0.301^{*}$ & 0.180 & $0.384^{* *}$ & $0.415^{* *}$ & 0.261 & $0.720^{* *}$ & -0.057 & 1 & -0.042 & -0.245 & 0.086 & 0.125 \\
\hline HI & $-1.000^{* *}$ & $-0.380^{* *}$ & $-0.550 * *$ & -0.260 & -0.110 & 0.000 & $0.816^{* *}$ & -0.182 & 1 & 0.008 & 0.079 & 0.122 \\
\hline STP & -0.143 & 0.016 & -0.102 & -0.036 & 0.144 & $-0.450^{* *}$ & $0.635^{* *}$ & -0.251 & 0.000 & 1 & $-0.789 * *$ & 0.112 \\
\hline MTP & -0.130 & -0.210 & -0.084 & 0.253 & 0.140 & $0.340^{*}$ & $-0.357^{*}$ & 0.088 & 0.000 & $-0.767^{* *}$ & 1 & -0.196 \\
\hline BTP & -0.029 & $0.418^{* *}$ & $0.490^{* *}$ & 0.038 & 0.273 & 0.016 & $0.436^{* *}$ & $0.350^{*}$ & $1.000 * *$ & $0.310^{*}$ & $-0.530 * *$ & 1 \\
\hline
\end{tabular}

${ }^{* *}=$ Correlation is highly significant at $\mathrm{p}<0.01,^{*}=$ Correlation is significant at $\mathrm{p}<0.05$, DE $=$ Days to emergence, $\mathrm{DF}=$ days to flowering, DM $=$ Days to maturity, $\mathrm{PH}=$ plant height, $\mathrm{SP}=$ Stems per plant, $\mathrm{TY}=$ Tuber yield, $\mathrm{TP}=$ Tubers per plant, $\mathrm{BY}=\mathrm{Biological}$ yield, $\mathrm{HI}=\mathrm{Harvest}$ index, $\mathrm{STP}=$ small tubers percentage, $\mathrm{MTP}=$ Medium tubers percentage, $\mathrm{BTP}=$ Big tubers percentage.

Table 3. Path coefficient analysis showing direct (bold) and indirect influence (off diagonal) of 11 characters on tuber yield of potato at phenotypic level.

\begin{tabular}{|c|c|c|c|c|c|c|c|c|c|c|c|c|}
\hline Trait & $\overline{D E}$ & DF & DM & PH & SP & TP & BY & HI & STP & MTP & BTP & $\mathbf{r}_{\mathrm{p}}$ \\
\hline$\overline{D E}$ & 0.4490 & -0.1410 & 0.1630 & -0.0490 & -0.1621 & -0.1513 & 0.1176 & -0.1064 & -0.0588 & 0.0529 & 0.0045 & 0.1560 \\
\hline DF & -0.1330 & -0.3010 & 0.0246 & 0.0791 & -0.0457 & -0.0508 & -0.0491 & 0.0283 & -0.0168 & 0.0608 & -0.0436 & -0.0060 \\
\hline DM & -0.0768 & 0.0173 & -0.2110 & -0.0660 & 0.0426 & 0.0989 & -0.0763 & 0.0291 & 0.0213 & 0.0173 & -0.0377 & 0.1000 \\
\hline PH & -0.0004 & -0.0959 & 0.1142 & 0.3650 & 0.0324 & -0.0489 & 0.1474 & -0.0248 & -0.1328 & 0.0919 & 0.0001 & $0.5740^{* *}$ \\
\hline SP & -0.1963 & 0.0826 & -0.1098 & 0.0484 & 0.5440 & 0.2442 & 0.1338 & -0.0152 & 0.0734 & 0.0397 & 0.0511 & $0.2890^{*}$ \\
\hline TP & -0.0007 & 0.0003 & -0.0009 & -0.0003 & 0.0009 & 0.0211 & -0.0001 & 0.0004 & 0.0126 & -0.0007 & 0.0297 & -0.0080 \\
\hline BY & 0.0875 & 0.0544 & 0.1209 & 0.1349 & 0.0821 & -0.0170 & 0.3340 & -0.0140 & -0.0818 & 0.0287 & 0.0417 & $0.6530^{* *}$ \\
\hline HI & -0.0706 & -0.0280 & -0.0411 & -0.0202 & -0.0008 & 0.0575 & -0.0125 & 0.2980 & 0.0002 & 0.0235 & 0.0363 & 0.0010 \\
\hline STP & 0.0745 & -0.0318 & 0.0574 & 0.2071 & -0.0768 & -0.3419 & 0.1394 & -0.0050 & -0.5690 & 0.4489 & 0.0637 & $-0.4230 * *$ \\
\hline MTP & 0.0487 & 0.0834 & 0.0338 & -0.1040 & -0.0301 & 0.1392 & -0.0355 & -0.0325 & 0.3258 & -0.4130 & 0.0809 & $0.3140^{*}$ \\
\hline BTP & 0.0001 & -0.0245 & -0.0302 & -0.0001 & -0.0158 & -0.0250 & -0.0211 & -0.0206 & -0.0189 & 0.0331 & -0.1690 & 0.0150 \\
\hline
\end{tabular}

Residual effect $=0.214,{ }^{* *}=$ is significant at $\mathrm{p}<0.01,{ }^{*}=$ Correlation is significant at $\mathrm{p}<0.05$, DE $=$ Days to emergence, $\mathrm{DF}=$ days to flowering, DM $=$ Days to maturity, $\mathrm{PH}=$ plant height, $\mathrm{SP}=$ Stems per plant, $\mathrm{TP}=$ Tubers per plant, BY = Biological yield, $\mathrm{HI}=\mathrm{Harvest}$ index, $\mathrm{STP}=\mathrm{small}$ tubers percentage, $\mathrm{MTP}=$ Medium tubers percentage, $\mathrm{BTP}=$ Big tubers percentage.

Table 4. Path coefficient analysis showing direct (bold) and indirect influence (off diagonal) of 11 characters on tuber yield of potato at genotypic level.

\begin{tabular}{|c|c|c|c|c|c|c|c|c|c|c|c|c|}
\hline Trait & $\mathrm{DE}$ & DF & $\mathrm{DM}$ & $\mathrm{PH}$ & SP & TP & BY & $\mathrm{HI}$ & STP & MTP & BTP & $\mathrm{rg}$ \\
\hline DE & -0.1530 & -0.0785 & -0.0627 & 0.0018 & 0.0621 & 0.0612 & -0.0461 & 0.1530 & 0.0218 & 0.0198 & 0.0044 & 0.1860 \\
\hline DF & 0.0938 & 0.1830 & -0.0154 & -0.0499 & 0.0298 & 0.0349 & 0.0329 & -0.0695 & 0.0029 & -0.0384 & 0.0765 & -0.0070 \\
\hline DM & -0.1496 & 0.0031 & -0.3650 & -0.1204 & 0.0781 & 0.1868 & -0.1402 & 0.2007 & 0.0372 & 0.0306 & -0.1788 & 0.1100 \\
\hline PH & -0.0012 & -0.0267 & 0.0323 & 0.0980 & 0.0098 & -0.0142 & 0.0406 & -0.0255 & -0.0035 & 0.0249 & 0.0037 & $0.6150^{* *}$ \\
\hline SP & -0.0434 & 0.0174 & -0.0228 & 0.0107 & 0.1070 & 0.0525 & 0.0279 & -0.0117 & 0.0154 & 0.0149 & 0.0292 & $0.3180^{*}$ \\
\hline TP & 0.0382 & 0.0208 & -0.0558 & -0.0158 & 0.0535 & 0.1090 & -0.0062 & 0.0889 & 0.0692 & -0.0389 & 0.0475 & -0.0150 \\
\hline BY & -0.1069 & 0.0228 & 0.0487 & 0.0527 & 0.0331 & -0.0072 & 0.1270 & -0.0231 & -0.0318 & 0.0112 & 0.0445 & $0.7200^{* *}$ \\
\hline HI & -0.095 & -0.0361 & -0.0523 & -0.0247 & -0.0104 & 0.0775 & -0.0171 & 0.0950 & 0.0000 & 0.0000 & 0.0950 & 0.0000 \\
\hline MTP & -0.0227 & -0.0367 & -0.014 & 0.0443 & 0.0245 & -0.0624 & 0.0154 & 0.0000 & 0.1342 & 0.1750 & -0.0927 & $0.3400^{*}$ \\
\hline BTP & -0.0024 & 0.0351 & 0.0411 & 0.0032 & 0.0229 & 0.0366 & 0.0294 & 0.0840 & 0.0260 & -0.0445 & 0.0840 & 0.0160 \\
\hline
\end{tabular}

Residual effect $=0.345,{ }^{* *}=$ is significant at $\mathrm{p}<0.01,^{*}=$ Correlation is significant at $\mathrm{p}<0.05, \mathrm{DE}=$ Days to emergence, $\mathrm{DF}=$ days to flowering, $\mathrm{DM}=$ Days to maturity, $\mathrm{PH}=$ plant height, $\mathrm{SP}=\mathrm{Stems}$ per plant, $\mathrm{TP}=$ Tubers per plant, $\mathrm{BY}=$ Biological yield, $\mathrm{HI}=\mathrm{Harvest}$ index, $\mathrm{STP}=\mathrm{small}$ tubers

percentage, $\mathrm{MTP}=$ Medium tubers percentage, $\mathrm{BTP}=$ Big tubers percentage

Khayatnezhad, Shahriari, \& Gholamin, (2011) also reported that there is a significant correlation between tuber yield with tuber number and tuber weight as well as plant height, main stem/plant, average tuber weight, tuber weight/plant. Therefore, improvement of tuber yield in potato is possible by using appropriate breeding strategy through selection for those positively correlated traits.

On the other hand, negative and strong significant correlation were found between small tuber and medium tuber percentage, days to maturity and tuber per plant, tuber per plant and stems per plant, days to emergence and stems per plant. This particularly indicates the importance of early maturing genotypes for higher yield per plant. Generally, increase in one of the character may lead to decrease in the other. This finding is in agreement with previous reports by Khayatnezhad et al. (2011) and Hamed, Saeed, Reza, \& Mostafa, (2011) who reported the presence of negative significant association between tuber 
per plant and medium tuber percentage, tuber yield and medium tuber percentage, small tuber percentage and medium tuber percentage as well as between tuber number and tuber weight.

\section{Path Coefficients}

Path coefficient analysis based on tuber yield as a dependent variable obtained positive direct effect for harvest index, stems per plant, days to emergence, tuber per plant, plant height and biological yield. The results of the path-analysis in Table 3 and 4 revealed that days to emergence, stems per plant, biological yield, and harvest index exerted positive highest phenotypic direct influence on tuber yield. However, days to flowering, days to maturity, small, medium and big tuber percentage exerted high negative direct influence on tuber yield. Conversely tuber per plant and plant height had positive and low direct effect on tuber yield. The stems per plant had the maximum direct effect on tuber yield followed by days to emergence. Similar to our finding, Sattar, Sultana, Hossain, Rashid, \& Islam, (2007) also reported that tuber per plant, average weight of tuber, number of compound leaves per plant had high positive direct effect on tuber yield. Strong negative direct effect were obtained for small tuber percentage, medium tuber percentage, days to flowering and days to maturity whereas small tuber percentage had high positive indirect effect via medium tuber percentage and vice versa. Days to maturity had high positive indirect effect through days to emergence, plant height and biological yield but low positive indirect effect via days to flowering, small and medium tuber percentage. The current findings were in congruence with the reports of Rasool, Mojtaba, \& Davood, (2006); Amadi, Ene-Obong, Okocha, \& Dung, (2008) and Khayatnezhad et al. (2011).

The highest positive genotypic direct effect was obtained for small tuber percentage followed by days to flowering, medium tuber percentage, biological yield, stems per plant while low were recorded for plant height, harvest index and big tuber percentage. However, days to maturity and days to emergence exerted highest negative direct influence on tuber yield. Small tuber percentage had strongest direct effect on tuber yield with low positive indirect effects via all the characters except medium tuber percentage. Whereas days to flowering had negative low indirect effect through days to emergence, plant height, harvest index and medium tuber percentage but low positive indirect effects were found for the rest characters. Consequently, such anomalous situation suggested that a restricted simultaneous selection model could be followed to nullify the undesirable indirect effects to make proper use of the direct effect.

The genotypic residual effect $(0.345)$ indicated that about $65.5 \%$ of the variability in tuber yield was contributed by the eleven characters studied in path analysis. About $34.5 \%$ of the variability towards yield in the present study might be due to many reasons such as other characters which were not studied, environmental factors and sampling errors as stated by Sengupta \& Karatia (1971). Within the scope of the path analysis carried out in the present investigation, it is, therefore, suggested that the small tuber percentage and days to flowering which are the main components of yield should be given high priority in the selection programme.

Generally, high yield with good quality is the most important objective in potato breeding. So, by considering the traits that have a strong positive association and correlation with tuber yield and the characters that show highest positive direct effect on tuber yield, Chiro, Gorobella, Bubu, Jalanie, Guassa, Bedassa, Belete, Gudanie and Zengena can be further used in the breeding programmes.

\section{References}

Amadi, C. O. (2005). Evaluation of potato genotypes for adaptation to heat stress. PhD Thesis, Michael Okpara University of Agriculture Umudike. 285pp.

Amadi, C. O., \& Ene-Obong, E. E. (2007). Genetic variability and inter-relationships of some potato attributes in Jos Plateau, Nigeria. Nigerian Journal of Botany, 20 (1), 233-245.

Amadi, C. O., Ene-Obong, E. E., Okocha, P. I. \& Dung, E. A. (2008). Path analysis of yield of some potato hybrids and their progenitors in Northern Guinea Savanna of Nigeria. Nigerian Journal of Botany, 4 (2), 28-37.

Birhman, R.K. \& Kang G. S. (1993). Analysis of variation and inter -relationships in potato germplasm. Euphytica, 68, 17-26. http://dx.doi.org/10.1007/BF00024150

Dewey, D. R. \& Lu, K. N. (1959). A correlation and path coefficient analysis of components of crested wheat grass seed production. Agronomy Journal, 51, 515-518.

http://dx.doi.org/10.2134/agronj1959.00021962005 100090002x

Ferdu, A., Bayeh, M., Emana, G., Temesgen, A., Eyob, T., Messele, G. \& Brook, W. (2009). Review of entomological research on root and tuber crops in Ethiopia. In: Abraham Tadesse. Increasing crop production through improved plant protection, Vol. 2. pp. 1-45. Plant Protection Society of Ethiopia (PPSE), PPSE and EIAR, Addis Ababa, Ethiopia.

Galarreta, J. I. R., Ezpelata, B., Pascualena, J. \& Ritter, E. (2006). Combining ability in early generations of potato breeding. Plant Breeding, 125, 183-186. http://dx.doi.org/10.1111/j.1439-0523.2006.01181.x

Guler, M., Adak, M. S., \& Ulukan, H. (2001). Determining the relationships amongst yield and some yield componets using path coefficient analysis in chickpea (Cicer arietinum L.). European Journal of Agronomy, 14 , 161-166. http://dx.doi.org/10.1016/S1161-0301(00)00086-1

Hamed, F., Saeed, A. G., Reza, A., \& Mostafa, A. (2011). Evaluating Correlation and Factor Analysis of 
Morphological Traits in Potato Cultivars in Fall Cultivation of Jiroft Area. Islamic Azad University, Jiroft Branch, Jiroft, Iran. Eurasian Journal of Agricultural \& Environmental Science, 11 (5), 679-684.

Johnson, H. W., Robinson, H. F. \& Comstock, R. E. (1955). Estimates of genetic and environmental variability in Soybean. Agronomy Journal, 47, 314-318. http://dx.doi.org/10.2134/agronj1955.00021962004 700070009x

Khayatnezhad, M., Shahriari, R., \& Gholamin, R. (2011). Correlation and path analysis between yield and yield components in Potato (Solanum tubersum L.). Young Researchers Club, Islamic Azad University, Ardabil Branch. Middle-East Journal of Scientific Research, 7 (1), 17-21.

Kumbhar, M. B., Larik, A. S. \& Hafiz, H. M. I. (1980). Biometrical association of yield and yield components in durum and bread wheat. Wheat Information Service, 54, 3537.

Kwon, S. H., Torrie, J. H. (1964). Heritability and interrelationship among traits of two soybean populations. Crop Science, 4,196-198. http://dx.doi.org/10.2135/cropsci1964.0011183X00 $0400020023 x$

Murat, T., \& Vahdettin, C. (2004). Relationships among traits using correlation and path coefficient analysis in Safflower (Carthamus tinctorius L.) sown in different fertilization levels and row spacing. Asian Journal of Plant Science, 3 (6), 683-686. http://dx.doi.org/10.3923/ajps.2004.683.686

Nandipuri, B. S., Singh, B. S., \& Lal, T. (1973). Studies on the genetic variability and correlation of some economic characters in tomato. Journal of Research, 10, 316-321.

Onder, M., \& Babaoglu, M. (2001). Interactions among grain variables in various dwarf dry bean (Phaseolus vulgaris L.) cultivars. Journal of Agronomy and Crop Science, 187, 10-23. http://dx.doi.org/10.1046/j.1439-037X.2001.00497.x

Radovan, M. (1992). Path-coeffficient analysis of some yield components of sunflower (Helianthus annuus L.). Euphytica, 60, 210-205.

Rasool, A, Mojtaba, F., \& Davood, H. (2006). Sequential path analysis of yield components in potato. Potato Research, 49, 273-279.

Sattar, M. A., Sultana, N., Hossain, M. M., Rashid, M. H. \& Islam, K. M. (2007). Genetic variability, correlation and path analysis in potato (Solanum tuberosum L.). Bangladesh Journal of Plant Breeding and Genetics, 20(1), http://dx.doi.org/10.3329/bjpbg.v20i1.17023

Sengupta, K., \& Karatia, A. S. (1971). Path co-efficients analysis for some characters in soybean. Indian Journal of Genetics, 31, 290-95.

Southern Nations, Nationalities and People's Regional State Finance and Economic Development Bureau (SNNPRFEDB), 2010. Investement in southern region. Brihan printing. Awassa. pp. 2.

Thompson, H. C., \& Kelly, W. C. (1957). Vegetable Crops. 5th Edition. Mc Graw Hill Book Company, Inc. New York, Toronto and London. pp. 611.
Tuncturk, M., \& Çiftçi, V. (2005). Selection criteria for potato breeding. Asian Journal of Plant Science, 4, 27-30. http://dx.doi.org/10.3923/ajps.2005.27.30

Upadhya, M. D. (1995). The potential of true potato seed technology for increased potato production in Bangladesh. Proceedings of the National Workshop on National Programme for True Potato Seed (TPS) in Bangladesh, May 5, 1995, Bangladesh Agricultural Research Council, Dhaka. p.5.

Yildirim, M. B., Çalikan, C. F., Çaylak, O., \& Budak, N. (1997). Multivariate relationships in potatoes. Second Turkish Field Crops Symposium, 22-25 September. Samsun, Turkey. (In Turkish). PMCid:PMC20871 